\title{
DAMPAK MEDIA SOSIAL DAN WORD OF MOUTH TERHADAP OVERTOURISM
}

\author{
Meitolo Hulu ${ }^{1}$, Fenisa Putri ${ }^{2}$, Michelle ${ }^{3}$, Stephanie Nathasya ${ }^{4}$ \\ ${ }^{1}$ Universitas Pelita Harapan, meitolo.hulu@uph.edu ${ }^{1}$
}

\begin{abstract}
ABSTRAK
Era digital telah mengubah gaya hidup masyarakat menjadi pengguna media sosial. Penggunaan media sosial menjadi meningkat dalam menyebarkan berita maupun dalam mencari berita. Informasi pariwisata dan berbagi pengalaman berwisata sering dilakukan oleh wisatawan melalui media sosial yang memicu ketertarikan calon wisatawan untuk berkunjung di suatu destinasi. Penelitian ini menganalisis dampak media sosial dan word of mouth terhadap over-tourism dengan pendekatan kuantitatif menggunakan alat analisis Smart PLS 3. Metode survey digunakan untuk menyebarkan kuesioner kepada 106 mahasiswa yang menggunakan media sosial dalam mencari informasi. Hasil penelitian ini menunjukkan bahwa media sosial dan word of mouth berpengaruh positif dan signifikan terhadap over-tourism. Artinya semakin banyak pengguna media sosial serta pelaku word of mouth memberikan kontribusi terhadap peningkatan jumlah wisatawan yang mengakibatkan terjadinya over-tourism. Pemangku kepentingan pariwisata harus mengelola media sosial dengan baik supaya tidak terjadi kesalah-pahaman baik dari pemberi informasi maupun penerima informasi, karena media sosial merupakan salah satu cara dalam membangun hubungan dengan wisatawan dan calon wisatawan.
\end{abstract}

Kata Kunci: media sosial, word of mouth, over-tourism, pariwisata, wisatawan

\section{ABSTRACT}

The digital era has changed people's lifestyles into social media users. The use of social media is increasing in spreading the news as well as in searching for news. Tourism information and sharing of travel experiences are often done by tourists through social media which triggers the interest of potential tourists to visit a destination. This study analyzes the impact of social media and word of mouth on over-tourism with a quantitative approach using the Smart PLS 3 analysis tool. The survey method was used to distribute questionnaires to 106 students who used social media to find information. The results of this study indicate that social media and word of mouth have a positive and significant effect on over-tourism. This means that more and more social media users and word of mouth actors contribute to the increase in the number of tourists which results in over-tourism. Tourism stakeholders must manage social media well so that there are no misunderstandings from both information givers and recipients of information, because social media is one way to build relationships with tourists and potential tourists.

Key words: Social media, word of mouth, over-tourism, tourism, tourists

\section{PENDAHULUAN}

Penggunaan media sosial di era digital sekarang ini sangat praktis dan mudah diakses oleh banyak orang. Masyarakat menggunakan media sosial untuk berbagai alasan seperti berkomunikasi, berbagi konten, pemasaran digital, dan bahkan mencari informasi
(Papadimitriou et al., 2018). Jaringan media sosial yang dapat menghubungkan banyak orang dengan dunia sekitar telah menjadi kebutuhan saat ini. Hal inilah yang menjadi alasan mengapa media sosial sering digunakan oleh sebagian besar wisatawan ketika ingin berwisata, dimana banyak menemukan informasi tentang

ISSN: 2355-6587, e-ISSN: 2528-2220

http://ejournal.bsi.ac.id/ejurnal/index.php/jp 
destinasi yang akan dikunjungi. Sebelum media sosial menjadi trend saat ini, word of mouth menjadi sarana pertama masyarakat dalam mencari informasi (East et al., 2016). word of mouth berpengaruh kuat dalam membantu wisatawan menentukan destinasi yang akan dikunjungi, karena word of mouth yang biasanya terjadi antara kerabat atau teman, juga tidak tertutup kemungkinan terjadi antar wisatawan.

Penduduk dunia yang mencapai 7,7 miliar, tercatat sekitar 3,6 miliar menggunakan media sosial (statistita,com, 2020). Data ini signifikan naik apabila dibandingkan dengan tahun 2014 yang menunjukkan bahwa pengguna internet di seluruh dunia diperkirakan telah melampaui 2,2 miliar atau sekitar 30 persen dari total populasi dunia (Rahmawati et al., 2019). Seiring dengan meningkatnya jumlah pengguna media sosial, menunjukkan keterbukaan akses informasi yang dapat mempengaruhi peningkatan jumlah wisatawan ke suatu destinasi.

Penyebaraan informasi melalui media sosial telah menjadi prioritas dalam strategi pemasaran. Citra destinasi yang dibangun melalui media sosial berdampak positif dalam penguatan destinasi dan kunjungan wisatawan (Lim et al., 2012). Kekuatan word of mouth saat ini tidak hanya dilakukan secara verbal tetapi lewat media online yang dikemas sebagai sebuah informasi atau berita (Kozinets et al., 2010). Berbagai informasi telah menjadi budaya bagi masyarakat saat ini, baik bersifat sosial maupun dengan tujuan komersil (Pezzuti \& Leonhardt, 2020). Destinasi wisata Venice, Italia telah berdampak buruk bagi ekosistem kota akibat eksploitasi dan ekplorasi yang berlebihan (Seraphin et al., 2018). Destinasi wisata membutuhkan promosi, namun harus di ikuti dengan kampanye konservasi yang megedukasi pengunjung.

Kelebihan kapasitas pengunjung di suatu wilayah yang menjadi destinasi wisata dialami oleh beberapa kota di dunia, dan bahkan di destinasi wisata alam (Bresson \& Logossah, 2011). Penelitian Jiricka-Pürrer et al., (2020) menunjukkan bahwa kunjungan wisata di beberapa kota di Eropa telah malampaui kapasitas. Fenomena over-tourism biasanya terjadi di destinasi wisata tertentu terutama pada saat liburan atau akhir pekan. Beberapa destinasi tersebut biasanya berada di pusat kota, di mana terdapat berbagai atraksi dan fasilitas yang dapat menarik wisatawan untuk berkunjung, baik itu museum, monumen, taman hiburan, atau tempat bersejarah. Sehingga banyak destinasi yang sering mengalami dampak overtourism. Pemahaman berwisata yang sering diartikan untuk bersenang-sennag yang ditandai dengan munculnya foto diri (selfie) di berbagai media sosial. Oleh karena itu, tujuan dari penelitian ini adalah untuk mengidentifikasi bagaimana dampak media sosial dan word of mouth menciptakan over-tourism dan sekaligus menganalisis dampak media sosial terhadap over-tourism.

\section{KAJIAN LITERATUR}

Media sosial merupakan teknologi berbasis internet yang digunakan oleh individu atau kelompok masyarakat untuk berkomunikasi, berbagi konten, bisnis, pemasaran digital, berbagi informasi, atau untuk tujuan hiburan (Barreto, 2014; Lim et al., 2012). Wisatawan saling berbagi pengalaman baik terkait produk maupun layanan, kemudian membagikan kepada calon pengunjung lainnya dengan tujuan mendidik atau sekedar untuk berbagi informasi (Baruah, 2012; Xiang \& Gretzel, 2010). Penggunaan media sosial telah mengubah gaya berkomunikasi yang tidak hanya berlangsusng pada komunitas tertentu tetapi juga interaksi dapat terjadi dari berbagai lapisan masyarakat. Interaksi berlangsung lebih mudah dan terjadi dua arah yang implikasinya positif bagi calon wisatawan (Baruah, 2012; Ring et al., 2016).

Industri pariwisata menjadikan teknologi sebagai bagian dalam pengembangan dan interaksi terhadap wisatawan maupun calon wisatawan. Komunikasi yang berlangsung antara industri pariwisata dan wisatawan bertujuan untuk membangun relasi dan menciptakan peluang ekonomi (Brida et 
al., 2020), baik yang dilakukan melalui media sosial maupun melalui word of mouth (Ruiz-Real et al., 2020). Interaksi langsung yang terjadi melalui media sosial dan word of mouth bermanfaat bagi destinasi maupun wisatawan itu sendiri dalam menentukan pilihannya. Selain biaya yang lebih rendah, media sosial juga memberikan layanan aksesibilitas yang lebih banyak. Namun, dalam menggunakan media sosial perlu mewaspadai kekeliruan baik dari sumber informasi maupun penerima informasi (Wu et al., 2019).

Penggunaan media sosial seperti Instagram, YouTube, Facebook, dan lain sebagainya digunakan wisatawan sebagai sumber informasi tentang berbagai tempat yang ingin dikunjungi. Mulai dari transportasi, akomodasi, destinasi wisata, dan sekaligus jenis layanan yang ditawarkan atau tersedia. Pemesanan hotel, tiket transportasi sampai pada paket perjalanan semuanya dapat dilakukan melalui internet dan telah menjadi pilihan utama wisatawan dan sekaligus membagikan pengalaman perjalanannya (Xiang \& Gretzel, 2010). Pemasaran produk-produk pariwisata yang dilakukan lewat media sosial sering menggunakan jasa orang lain atau public figure supaya menjadi lebih menarik dan dipercaya oleh calon wisatawan (Knoll \& Matthes, 2017). Hal ini dilakukan dengan membuat konten menarik dan mendorong pembaca untuk menyukai, berkomentar, dan membagikannya melalui jejaring sosial yang dimiliki. Dengan demikian, setiap orang secara tidak langsung berperan sebagai agen pemasaran pariwisata dan membantu meningkatkan minat wisatawan untuk berlibur.

Strategi promosi yang dilakukan melalui word of mouth adalah kegiatan berupa pujian, rekomendasi dan komentar dari wisatawan tentang pengalaman dengan layanan dan produk pariwisata (Lindberg-Repo \& Grönroos, 1999; Mada, 2020), sekaligus sebagai upaya perusahaan dalam memperkenalkan beragam produk dan layanan kepada calon konsumen (Yulianto \& Hari Putri, 2021). Sekarang ini word of mouth tidak hanya dapat disebarkan dari mulut ke mulut, tetapi juga dapat disebarkan melalui media sosial yang lebih dikenal dengan electronic word of mouth (e-WOM) dengan efektif dan cepat. Menurut Luarn et al., (2016) bahwa motivasi word of mouth adalah untuk beriteraksi dengan kolega dalam membangun hubungan, mengidentifikasi kebutuhan pelanggan, dan meningkatkan minat untuk melakukan word of mouth.

Over-tourism adalah suatu keadaan dimana pengunjung lebih banyak dari pada penduduk lokal yang menimbulkan dampak negatif baik terhadap pengunjung maupun penduduk lokal (Pezzuti \& Leonhardt, 2020). Over-tourism menggambarkan kondisi destinasi yang padat dipenuhi wisatawan dan melebihi jumlah penduduk setempat (Aris Anuar et al., 2019). Program-program pemasaran wisata yang tidak terkendali, seperti pemberian diskon pada harga akomodasi, transportasi, maupun paket wisata pada kurun waktu tertentu menjadi salah satu pemicu terjadinya kepadatan wisatawan pada waktu yang bersamaan. Kepadatan wisatawan di destinasi tidak hanya mengurangi tingkat kepuasan wisatawan tetapi juga mengurangi kualitas dari destinasi tersebut. Over-tourism tidak hanya disebabkan oleh kelebihan wisatawan tetapi juga merupakan penggunaan infrastruktur, eksploitasi kawasan wisata yang berlebihan dan tidak dikelola secara berkelanjutan (UNWTO, 2018; Koens et al., 2018). Untuk itu sangat diperlukan kolaborasi antara pemangku kepentingan terkait, berorientasi pada pelibatan mayarakat lokal dalam mengembangan kawasan wisata yang berkelanjutan (Hulu, 2021).

UNWTO (2018) mencatat beberapa dampak yang ditimbulkan akibat overtourism adalah terjadinya kerusakan lokasi wisata, pencemaran udara, sampah, dan masalah sosial di sekitar destinasi wisata. Bahwa pariwisata membawa dampak positif terhadap ekonomi masyarakat lokal harus diikuti dengan pengelolaan yang inovatif dan berkelanjtuan (Eide et al., 2017). Media sosial yang tersedia melalui teknologi seluler, sangat mendukung kegiatan pemasaran karena peningkatan pengguna yang semakin signifikan naik 
(Yadav et al., 2015). Media sosial yang memiliki banyak kegunaan telah mengubah gaya berkomunikasi di antara industri pariwisata dan wisatawan yang berkontribusi pada jumlah kunjungan wisatawan ke suatu destinasi (AlonsoAlmeida et al., 2019).

Saat ini media sosial berperan penting sebagai sumber informasi wisata, baik melalui konten, foto, word of mouth yang dapat menjangkau semua kalangan. Selain itu, media sosial tidak hanya menguatkan citra destinasi, tetapi juga mempengaruhi orang lain dalam memilih destinasi yang akan dikunjungi. Karena media sosial dan word of mouth telah banyak digunakan dalam kegiatan pariwisata, maka penelitian ini dilakukan untuk menemukan jawaban mengenai dampak media sosial dan word of mouth terhadap over-tourism di destinasi wisata. Berikut adalah hipotesis dalam penelitian ini:

H1: Media sosial berpengaruh positif dan signifikan terhadap over-tourism.

$\mathrm{H} 2$ : Word of mouth berpengaruh positif dan signifikan terhadap over-tourism.

\section{METODE PENELITIAN}

Penelitian ini menggunakan pendekatan kuantitatif untuk mengetahui hubungan antara dua variabel yaitu media exogen dan variabel over-tourism sebagai variabel endogen. Alasannya, penelitian ini berfokus pada pengukuran perilaku responden untuk menganalisis dampak media sosial dan word of mouth terhadap over-tourism. Penelitian kuantitatif sosial dan word of mouth sebagai variabel

merupakan salah satu jenis kegiatan penelitian yang spesifikasinya sistematis, terencana, dan terstruktur dengan jelas sejak awal hingga pembuatan desain penelitian, baik mengenai tujuan penelitian, subjek penelitian, objek penelitian, sampel data, sumber data, maupun metodologi. Oleh karena itu, penelitian kuantitatif melibatkan dirinya dalam perhitungan atau angka atau kuantitas (Sugiyono, 2014).

Metode survey digunakan dalam penelitian ini yang memungkinkan peneliti untuk menghasilkan data yang lebih baik melalui prosedur pengumpulan data berdasarkan konsep instrumen penelitian dari variabel terkait antara dampak media sosial, word of mouth terhadap overtourism.

Dalam penelitian ini, kuesioner disebarkan untuk mengumpulkan data yang dilakukan secara online melalui google form karena lebih efektif dan sesuai dengan protokol kesehatan. Peneliti menyebar kuesioner kepada individu yang pernah berlibur dan kemudian di analisis menggunakan Smart PLS 3.0. Menurut Ghozali \& Latan (2014) Partial Least Square (PLS) bersifat soft modelling yang tidak berpatokan pada asumsi data melainkan pada skala pengukuran, distribusi data, dan jumlah sampel.

Evaluasi model dalam penelitian ini dilakukan melalui evaluation measurenment model dan evaluation of structural model. Peneliti menyebarkan 17 item kuesioner kepada mahasiswa UPH yang pernah atau sering berlibur baik secara individu maupun keluarga.

\section{Tabel 1. Indikator Penelitian}

\begin{tabular}{|c|c|c|c|c|}
\hline No & Pertanyaan & 1 & 2 & 3 \\
\hline 1 & Media sosial sudah menjadi kebutuhan di era modern ini & & & \\
\hline 2 & $\begin{array}{l}\text { Setiap hari pasti menggunakan media sosail untuk mencari } \\
\text { informasi }\end{array}$ & & & \\
\hline 3 & $\begin{array}{l}\text { Media sosial digunakan untuk memposting foto dan pengalaman } \\
\text { perjalanan wisata }\end{array}$ & & & \\
\hline 4 & Media sosial efektif untuk mempromosikan destinasi wisata & & & \\
\hline 5 & Tertarik dengan destinasi wisata karena melihat dari media sosial & & & \\
\hline 6 & $\begin{array}{l}\text { Mengunjungi destinasi wisata yang viral karena melihat dari } \\
\text { media sosial }\end{array}$ & & & \\
\hline 7 & $\begin{array}{l}\text { Tertarik dengan destinasi wisata karena di beritahu oleh } \\
\text { teman/keluarga }\end{array}$ & & & \\
\hline
\end{tabular}

ISSN: 2355-6587, e-ISSN: 2528-2220

http://ejournal.bsi.ac.id/ejurnal/index.php/jp 


\begin{tabular}{ll|l|l|l}
\hline 8 & $\begin{array}{l}\text { Berkunjung ke destinasi karena sering dibicarakan oleh banyak } \\
\text { orang }\end{array}$ & & & \\
\hline 9 & $\begin{array}{l}\text { Promosi destinasi wisata efektif bila dilakukan melalui word of } \\
\text { mouth }\end{array}$ & & & \\
\hline 10 & $\begin{array}{l}\text { Destinasi yang telah dikunjungi perlu merekomendasikan kepada } \\
\text { teman/keluarga }\end{array}$ & & & \\
\hline 11 & $\begin{array}{l}\text { Destinasi yang sedang viral berpengaruh pada keputusan untuk } \\
\text { berwisata }\end{array}$ & $\begin{array}{l}\text { Ketika liburan tertarik mengunjungi beberapa tempat wisata yang } \\
\text { ada di sekitar destinasi }\end{array}$ & & \\
\hline 13 & Destinasi yang ramai berpengaruh terhadap kepuasan liburan & & \\
\hline 14 & Berwisata di destinasi yang ramai mempengaruhi kenyamanan & & \\
\hline 15 & Keselamatan adalah prioritas dalam memilih destinasi & & \\
\hline 16 & Kebersihan destinasi wisata adalah merupakan faktor penting & & \\
\hline 17 & Daya tarik wisata adalah cerminan dari kualitas destinasi & & \\
\hline Su & & & \\
\hline
\end{tabular}

Sumber: Dimodifikasi dari Mada (2020); Ruiz-Real et al., (2020); Wu et al., (2019); UNWTO (2018); Koens et al., (2018); Luarn et al., (2016).

Pemilihan responden dari kalangan peneliti dalam pilihan ganda dengan mahasiswa karena merupakan generasi jawaban skala likert (1 sampai 4). Dengan muda yang telah mengalami era keterangan nomor 1 adalah sangat tidak modernisasi terutama dalam penggunaan setuju, nomor 2 adalah tidak setuju, nomor media sosial. Pada lembar kuesioner, 3 adalah setuju, dan nomor 4 adalah sangat pilihan jawaban angket telah diberikan setuju. Berikut adalah daftar pertanyaan.

\section{PEMBAHASAN}

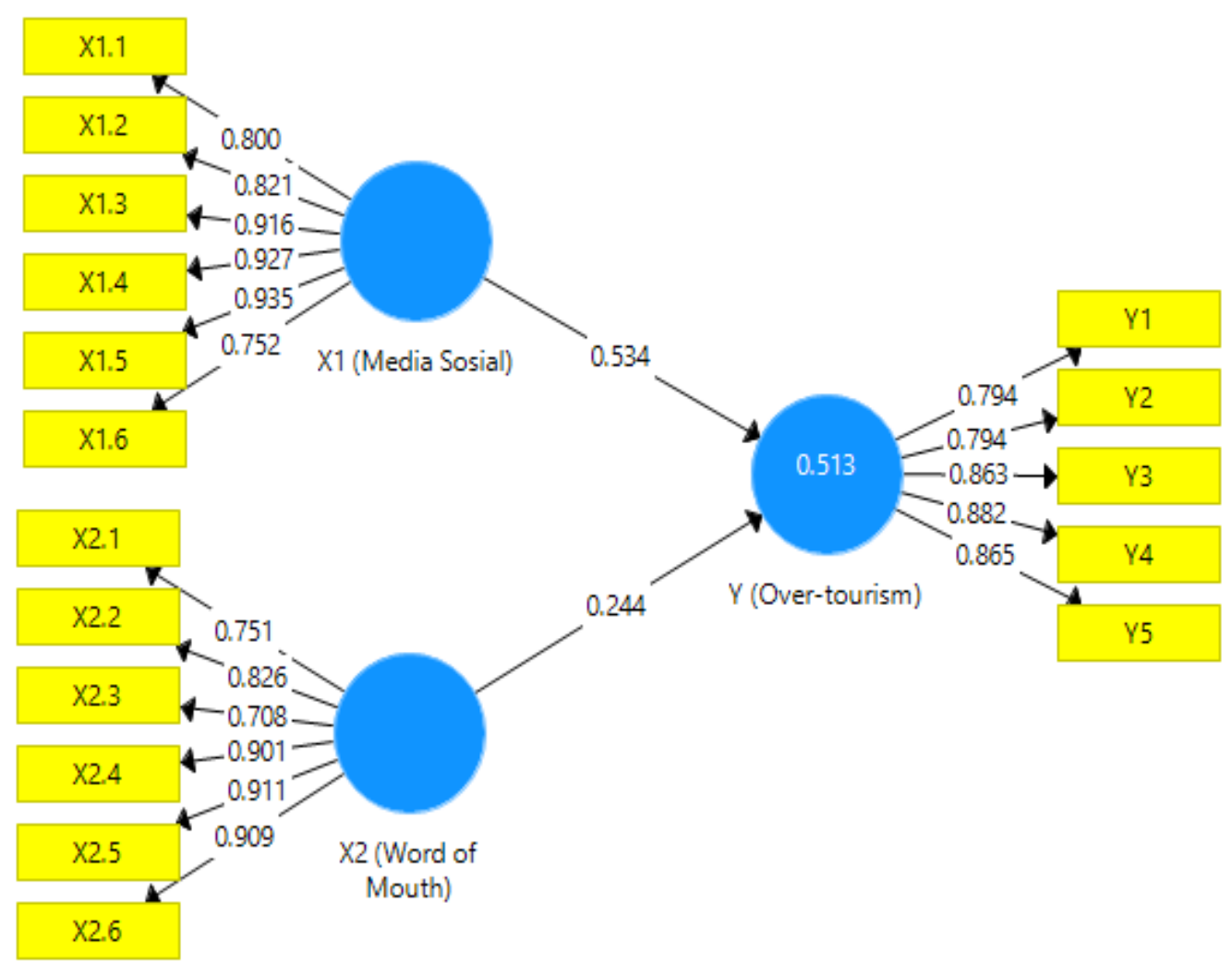

\section{Gambar 1}

Loading Factor pada model pengukuran

Sumber : Output data primer yang diolah (2021) 
Berdasarkan gambar 1 terlihat bahwa semua item kuesioner telah memenuhi standar uji validitas yaitu nilai factor loading $>0,7$.

Evaluasi model Pengukuran yang disajikan pada gambar dan tabel berikut ini adalah evaluasi pada convergent validity dan discriminant validity dengan menunjukkan nilai loading factor, AVE, Fornell larcker, dan cross loading.

Tabel 2. Average Variance Extracted

\begin{tabular}{lrr}
\hline & $\begin{array}{l}\text { Composite } \\
\text { Reliability }\end{array}$ & \multicolumn{2}{l}{$\begin{array}{l}\text { Average Variance } \\
\text { Extracted (AVE) }\end{array}$} \\
\hline X1 (Media Sosial) & 0.945 & 0.742 \\
\hline X2 (Word of Mouth) & 0.934 & 0.703 \\
\hline Y (Over Tourism) & 0.923 & 0.706 \\
\hline
\end{tabular}

Sumber : Data diolah (2021)

Pada Evaluatian of Structural Model signifikansi masing-masing variable dan menampilkan tabel composite reliability nilai AVE $>0,5$ yaitu nilai yang dimiliki serta nilai $\mathrm{R}$ sguare dan nilai $\mathrm{t}$-statistic oleh setiap variabel telah memenuhi syarat. yang menunjukkan tingkat pengaruh dan

Tabel 3. Fornell Larcker Criterion

\begin{tabular}{lrrr}
\hline & X1 (Media Sosial) & X2 (Word of Mouth) & Y (Over Tourism) \\
\hline X1 (Media Sosial) & 0.862 & & \\
\hline X2 (Word of Mouth) & 0.648 & 0.838 & \\
\hline Y (Over Tourism) & 0.692 & 0.590 & 0.840 \\
\hline
\end{tabular}

Sumber : Data diolah (2021)

Tabel 3 menunjukkan nilai korelasi itu sendiri lebih besar dari nilai korelasi masing-masing variabel dengan variabel variabel dengan variabel lain.

Tabel 4. Cross Loading

\begin{tabular}{cccc}
\hline & X1 (Media Sosial) & X2 (Word of Mouth) & Y (Over Tourism) \\
\hline $\mathrm{X} 1.1$ & 0.800 & 0.417 & 0.563 \\
\hline $\mathrm{X} 1.2$ & 0.821 & 0.458 & 0.597 \\
\hline $\mathrm{X} 1.3$ & 0.916 & 0.562 & 0.611 \\
\hline $\mathrm{X} 1.4$ & 0.927 & 0.581 & 0.628 \\
\hline $\mathrm{X} 1.5$ & 0.935 & 0.630 & 0.655 \\
\hline $\mathrm{X} 1.6$ & 0.752 & 0.718 & 0.510 \\
\hline $\mathrm{X} 2.1$ & 0.518 & 0.751 & 0.406 \\
\hline $\mathrm{X} 2.2$ & 0.518 & 0.826 & 0.503 \\
\hline $\mathrm{X} 2.3$ & 0.312 & 0.708 & 0.449 \\
\hline $\mathrm{X} 2.4$ & 0.613 & 0.901 & 0.517 \\
\hline $\mathrm{X} 2.5$ & 0.656 & 0.911 & 0.554 \\
\hline $\mathrm{X} 2.6$ & 0.610 & 0.909 & 0.521 \\
\hline $\mathrm{Y} 1$ & 0.471 & 0.508 & 0.794 \\
\hline $\mathrm{Y} 2$ & 0.499 & 0.502 & 0.794 \\
\hline $\mathrm{Y} 3$ & 0.679 & 0.513 & 0.863 \\
\hline $\mathrm{Y} 4$ & 0.659 & 0.507 & 0.882 \\
\hline $\mathrm{Y} 5$ & 0.565 & 0.454 & 0.865 \\
\hline
\end{tabular}

Sumber : Data diolah (2021)

Berdasarkan tabel 4 di atas menunjukkan bahwa nilai korelasi antara indikator dengan varibel laten lebih tinggi dari nilai korelasi antara indikator dengan variabel laten lainnya. Dari hasil yang di tunjukkan

pada Gambar 1, tabel 2, tabel 3, dan tabel 4 menunjukkan bahwa uji validitas yang dilakukan melalui uji convergent validity dan discriminant validity telah memenuhi syarat. 
Tabel 5. Composite Reliability

\begin{tabular}{ll}
\hline \multicolumn{2}{c}{ Composite Reliability } \\
\hline X1 (Media Sosial) & 0.945 \\
\hline X2 (Word of Mouth) & 0.934 \\
\hline Y (Over Tourism) & 0.923 \\
\hline
\end{tabular}

Sumber : Data diolah (2021)

Tabel 5 menunjukkan Nilai uji composite reability > 0,7 yang berarti seluruh variabel dinyatakan reliabel.

Tabel 6 Nilai path coefisien dan $t$-statistik

\begin{tabular}{llcccr}
\hline & $\begin{array}{l}\text { X1 (Media } \\
\text { Sosial) }\end{array}$ & $\begin{array}{l}\text { X2 (Word } \\
\text { of Mouth) }\end{array}$ & $\begin{array}{l}\text { Y (Over } \\
\text { Tourism) }\end{array}$ & R Square & T-Statistik \\
\hline X1 (Media Sosial) & & & 0.534 & 5.241 \\
\hline X2 (Word of Mouth) & & 0.244 & 2.146 \\
\hline Y (Over Tourism) & & & 0.513 & \\
\hline
\end{tabular}

Sumber : Data diolah (2021)

Pada tabel 6, Nilai R sguare sebesar 0,513 artinya 51,3 persen variabel over-tourism dipengaruhi oleh variabel media sosial dan word of mouth, sementara sisanya 49,7 persen dipengaruhi oleh faktor lain. Sementara arah hubungan variabel media sosial berpengaruh positif terhadap variabel over-tourism. Pada nilai t-statistik menunjukkan bahwa variabel media sosial dan variabel word of mouth lebih besar dari 1.96, artinya variabel media sosial dan variabel word of mouth berpengaruh positif dan signifikan terhadap variabel overtourism.

Berdasarkan data dan hasil analisis membuktikan bahwa hipotesis 1 yaitu media sosial berpengaruh posistif dan signifikan terhadap over-tourism. Hal ini menunjukkan bahwa penyebaran berita melalui media sosial adalah bagian dari strategi pemasaran dan menjangkau pasar yang lebih luas. Hasil ini selaras dengan penelitian Xiang \& Gretzel (2010) dan (Knoll \& Matthes, 2017). Namun, dalam menggunakan media sosial perlu mewaspadai kekeliruan baik dari sumber informasi maupun penerima informasi $(\mathrm{Wu}$ et al., 2019).

Hipotesis 2 yaitu word of mouth juga berpengaruh posistif dan signifikan terhadap over-tourism. Hal ini menunjukkan bahwa semakin sering melakukan word of mouth maka akan semakin menarik perhatian wisatawan dalam mengunjungi destinasi wisata. karena era modernisasi ini orang lebih cenderung mendapatkan banyak informasi khususnya mengenai destinasi wisata secara online, maka diperlukan pengelolaan berita yang dapat memberi edukasi dan sekaligus pemahaman yang benar mengenai kondisi destinasi wisata yang sebenarnya. Penerimaan informasi melalui media online perlu di konfirmasi ulang kepada pengelola destinasi atau pemangku kepentingan terkait supaya tidak terjadi kesalah-pahaman.

\section{PENUTUP}

Media sosial dan word of mouth berpengaruh positif dan signifikan terhadap over-tourism perlu direspon oleh pemangku kepentingan, baik pengelola destinasi wisata maupun pemerintah. Terlepas dari dampak negatif yang ditimbulkan maka perlu diketahui bahwa destinasi wisata perlu inovasi dalam promosi untuk menjangkau semua caloncalon wisatawan. Untuk penelitian selanjutnya perlu menganalisis faktor biaya perjalanan, dan aksesibilitas yang dapat berpengaruh terhadap ketertarikan wisatawan dalam mengunjugi destinasi wisata yang berdampak pada over-tourism.

\section{REFERENSI}

Alonso-Almeida, M. del M., BorrajoMillán, F., \& Yi, L. (2019). Are

ISSN: 2355-6587, e-ISSN: 2528-2220

http://ejournal.bsi.ac.id/ejurnal/index.php/jp 
social media data pushing overtourism? The case of Barcelona and Chinese Tourists. Sustainability (Switzerland), 11(12), 1-17. https://doi.org/10.3390/SU11123356

Aris Anuar, A. N., Ridzuan, F. H., Jaini, N., Sulaiman, F. C., \& Hashim, N. I. (2019). The Impact of Overtourism Towards Local Community in Heritage City. Journal of Tourism \& Hospitality, 08(03), 1-5. https://doi.org/10.35248/21670269.19.8.406

Barreto, A. M. (2014). The word-of-mouth phenomenon in the social media era. International Journal of Market Research, 56(5), 631-654. https://doi.org/10.2501/IJMR-2014043

Baruah, T. D. (2012). Effectiveness of Social Media as a tool of communication and its potential for technology enabled connections. International Journal of Scientific and Research Publications, 2(5).

Bresson, G., \& Logossah, K. (2011). Crowding-out effects of cruise tourism on stay-over tourism in the caribbean: Non-parametric panel data evidence. Tourism Economics, 17(1), 127-158. https://doi.org/10.5367/te.2011.0028

Brida, J. G., Matesanz Gómez, D., \& Segarra, V. (2020). On the empirical relationship between tourism and economic growth. Tourism Management, 81(3), 352-363. https://doi.org/10.1016/j.tourman.202 0.104131

East, R., Uncles, M. D., Romaniuk, J., \& Lomax, W. (2016). Measuring the impact of positive and negative word of mouth: A reappraisal. Australasian Marketing Journal, 24(1), 54-58. https://doi.org/10.1016/j.ausmj.2015. 12.003

Eide, D., Fuglsang, L., \& Sundbo, J. (2017). Management challenges with the maintenance of tourism experience concept innovations: Toward a new research agenda. Tourism Management, 63, 452-463. https://doi.org/10.1016/j.tourman.201
7.06.029

Ghozali, I., \& Latan, H. (2014). Imam, G., \& Latan, H. (2014). Partial Least Square (PLS) konsep teknik dan aplikasi. Semarang: Universitas Diponegoro Semarang . 2014.

Hulu, M. (2021). Partisipasi Kolaboratif Pengembangan Kawasan Wisata Berkelanjutan (1st ed.). Valemba.

Jiricka-Pürrer, A., Brandenburg, C., \& Pröbstl-Haider, U. (2020). City tourism pre- and post-covid-19 pandemic - Messages to take home for climate change adaptation and mitigation? Journal of Outdoor Recreation and Tourism, 31. https://doi.org/10.1016/j.jort.2020.10 0329

Knoll, J., \& Matthes, J. (2017). The effectiveness of celebrity endorsements: a meta-analysis. Journal of the Academy of Marketing Science, 45(1), 55-75. https://doi.org/10.1007/s11747-0160503-8

Koens, K., Postma, A., \& Papp, B. (2018). Is overtourism overused? Understanding the impact of tourism in a city context. Sustainability (Switzerland), 10(12), 1-15. https://doi.org/10.3390/su10124384

Kozinets, R. V., De Valck, K., Wojnicki, A. C., \& Wilner, S. J. S. (2010). Networked narratives: Understanding word-of-mouth marketing in online communities. Journal of Marketing, 74(2), 71-89. https://doi.org/10.1509/jmkg.74.2.71

Lim, Y., Chung, Y., \& Weaver, P. A. (2012). The impact of social media on destination branding: Consumergenerated videos versus destination marketer-generated videos. Journal of Vacation Marketing, 18(3), 197206.

https://doi.org/10.1177/13567667124 49366

Lindberg-Repo, K., \& Grönroos, C. (1999). Word-Of-Mouth Referrals in the Domain of Relationship Marketing. Australasian Marketing Journal, 7(1), 109-117. https://doi.org/10.1016/s1441 - 
3582(99)70208-9

Luarn, P., Huang, P., Chiu, Y. P., \& Chen, I. J. (2016). Motivations to engage in word-of-mouth behavior on social network sites. Information Development, 32(4), 1253-1265. https://doi.org/10.1177/02666669155 96804

Mada, Y. P. (2020). Social Media Marketing, Electronic Word of Mouth Dan Customer Engagement. Journal of Management Studies, 14(1), 80-91.

Papadimitriou, D., Kaplanidou, K. (Kiki), \& Apostolopoulou, A. (2018). Destination Image Components and Word-of-Mouth Intentions in Urban Tourism: A Multigroup Approach. Journal of Hospitality and Tourism Research, 42(4), 503-527. https://doi.org/10.1177/10963480155 84443

Pezzuti, T., \& Leonhardt, J. M. (2020). How collectivistic values affect online word-of-mouth. International Journal of Market Research, 147078532092920.

https://doi.org/10.1177/14707853209 29200

Rahmawati, H. N., Iqomh, M. K. B., \& Hermanto, H. (2019). Hubungan Durasi Penggunaan Media Sosial Dengan Motivasi Belajar Remaja. Jurnal Keperawatan Jiwa, 5(2), 77. https://doi.org/10.26714/jkj.5.2.2017. 77-81

Ring, A., Tkaczynski, A., \& Dolnicar, S. (2016). Word-of-Mouth Segments: Online, Offline, Visual or Verbal? Journal of Travel Research, 55(4), 481-492.

https://doi.org/10.1177/00472875145 63165

Ruiz-Real, J. L., Uribe-Toril, J., \& Gázquez-Abad, J. C. (2020). Destination branding: Opportunities and new challenges. Journal of Destination Marketing and Management, 17(June). https://doi.org/10.1016/j.jdmm.2020. 100453

Seraphin, H., Sheeran, P., \& Pilato, M. (2018). Over-tourism and the fall of
Venice as a destination. Journal of Destination Marketing and Management, 9(January), 374-376. https://doi.org/10.1016/j.jdmm.2018. 01.011

Sugiyono. (2014). Metode Penelitian Kuantitatif dan Kualitatif dan $R \& D$. 2014.

UNWTO. (2018). 'Overtourism'? Understanding and Managing Urban Tourism Growth beyond Perceptions, Executive Summary. 'Overtourism'? - Understanding and Managing Urban Tourism Growth beyond Perceptions, Executive Summary. https://doi.org/10.18111/9789284420 070

Wu, L., Morstatter, F., Carley, K. M., \& Liu, H. (2019). Misinformation in Social Media: Definition, Manipulation, and Detection. ACM SIGKDD Explorations Newsletter, 21(2), 80-90. https://www.nytimes.com/2016/11/21 /technology/fact-

Xiang, Z., \& Gretzel, U. (2010). Role of social media in online travel information search. Tourism Management, 31(2), 179-188. https://doi.org/10.1016/j.tourman.200 9.02.016

Yadav, M., Joshi, Y., \& Rahman, Z. (2015). Mobile Social Media: The New Hybrid Element of Digital Marketing Communications. Procedia - Social and Behavioral Sciences, 189, 335-343. https://doi.org/10.1016/j.sbspro.2015. 03.229

Yulianto, A., \& Hari Putri, E. D. (2021). Strategi Pengembangan Daya Tarik Untuk Mendukung Promosi Desa Wisata Puspoardi Yogyakarta. Jurnal Pariwisata, 8(1), 51-62. https://doi.org/10.31294/par.v8i1.101 25

\section{BIODATA PENULIS}

Meitolo Hulu adalah dosen Fakultas Pariwisata Universitas Pelita Harapan. dengan latar belakang pendidikan kajian pariwisata, tertarik dengan penelitian pariwisata berkelanjutan, partisipasi

ISSN: 2355-6587, e-ISSN: 2528-2220

http://ejournal.bsi.ac.id/ejurnal/index.php/jp 
masyarakat. Mengampu mata kuliah inovasi dan keberlanjutan pariwisata, manajemen investasi dan studi kelayakan bisnis, dan manajemen tata graha.

Fenisa Putri adalah mahasiswi Program Studi Pengelolaan Perhotelan Fakultas Pariwisata Universitas Pelita Harapan.
Michelle adalah mahasiswi Program Studi Pengelolaan Perhotelan Fakultas Pariwisata Universitas Pelita Harapan.

Stephanie Nathasya adalah mahasiswi Program Studi Pengelolaan Perhotelan Fakultas Pariwisata Universitas Pelita Harapan. 